J. Lake Sci. (湖泊科学), 2015, 27(2):227-233

http: //www. jlakes. org. E-mail : jlakes@niglas.ac.cn

(c) 2015 by Journal of Lake Sciences

\title{
宜兴太湖防护林对农业面源污染的减源增汇作用浅析”
}

\author{
孙 慧 $^{1}$, 张建锋 ${ }^{1 * *}$, 单奇华 ${ }^{2}$, 汪庆兵 ${ }^{1}$, 陈光才 ${ }^{1}$, 吴 灏 $^{1}$ \\ ( 1 : 中国林业科学研究院亚热带林业研究所, 富阳 311400) \\ ( 2 : 江苏省宜兴市农林局,宜兴 214206)
}

\begin{abstract}
摘 要: 为探讨太湖沿岸防护林宜兴段对农业面源污染物的控制效果, 通过在宜兴市太湖防护林采集土壤样品, 测定其 中营养元素含量,结合周边农业生产施肥概况,初步分析了该区域防护林对农业面源污染的减源一增汇效应. 结果表明, 2009 年 10 月份防护林地上部分固定的 C、N、P 和 K 分别为 $2439.48 、 18.34 、 2.48$ 和 $13.42 \mathrm{~g} / \mathrm{m}^{2} ; 2011$ 年 5 月份固定量分 别为 $3114.12 、 23.42 、 3.16$ 和 $17.13 \mathrm{~g} / \mathrm{m}^{2}$; 而 2013 年 8 月份固定量分别为 $4722.46 、 35.53 、 4.81$ 和 $25.99 \mathrm{~g} / \mathrm{m}^{2}$. 可见 $\mathrm{C} 、 \mathrm{~N}$ 、 $\mathrm{P}$ 和 $\mathrm{K}$ 的固定量是逐年增加的,相比 2009 年,分别增加了 $93.6 \% 、 93.7 \% 、 94.0 \%$ 和 $93.7 \%$. 结果说明宜兴段太湖沿岸防 护林对农业面源污染的控制效果较显著, 有助于太湖水污染的治理.
\end{abstract}

关键词: 太湖;宜兴;防护林;面源污染;减源;增汇

\section{Preliminary analysis of the source reduced and sink increased for agricultural non-point source pollution by forest in Lake Taihu watershed: A case study of shelter belt in Yixing City}

\author{
SUN Hui ${ }^{1}$, ZHANG Jianfeng ${ }^{1}$, SHAN Qihua ${ }^{2}$, WANG Qingbing ${ }^{1}$, CHEN Guangcai $^{1} \&$ WU Hao ${ }^{1}$ \\ (1: Institute of Subtropical Forestry, Chinese Academy of Forestry, Fuyang 311400, P. R. China) \\ (2: Yixing Agriculture and Forestry Department, Jiangsu Province, Yixing 214206, P. R. China)
}

\begin{abstract}
To inquire the control effect of agricultural non-point source pollution by the shelter forest of Lake Taihu in Yixing City, the soil samples in the shelter forest belt were collected and the contents of nutrient elements were determined. Combined with the fertilization conditions of surrounding agricultural production, the source reduced and sink increased for agricultural non-point source pollution by the shelter forest in Yixing City was analyzed. The results showed that the C, N, P and K which were fixed by the shelter forest were $2439.48,18.34,2.48$ and $13.42 \mathrm{~g} / \mathrm{m}^{2}$ in October 2009 , and $3114.12,23.42,3.16$ and $17.13 \mathrm{~g} / \mathrm{m}^{2}$ in May 2011, respectively. The fixed values showed a trend of gradually increasing, reaching to 4722.46, 35.53, 4.81 and 25.99 $\mathrm{g} / \mathrm{m}^{2}$ in $\mathrm{C}, \mathrm{N}, \mathrm{P}$ and $\mathrm{K}$ in August 2013. The increased proportions of $\mathrm{C}, \mathrm{N}, \mathrm{P}$ and $\mathrm{K}$ were $93.6 \%, 93.7 \%, 94.0 \%$ and $93.7 \%$ respectively when compared with October 2009. The above results showed that the control effect of agricultural non-point source pollution by the shelter forest belt in Yixing City around the Lake Taihu coast was significant, and it had a big contribution to the management of water pollution in Lake Taihu.
\end{abstract}

Keywords: Lake Taihu; Yixing City; shelter forest; non-point source pollution; source reduced; sink increased

太湖是我国第三大淡水湖,近年来随着太湖流域周边地区经济的快速发展, 人们过多地注重经济效益 而忽略了生态效益,直接导致了 2007 年 5 月底太湖暴发 “蓝藻危机” ${ }^{[14]}$. 其实, 太湖水体污染问题由来已 久,人们一直关注的是工业点源污染的整治,在点源污染得到有效治理后,太湖水体环境并未得到根治,进 而人们认识到面源污染同时也是引起水污染的重要原因 ${ }^{[5-8]}$. 面源污染又称非点源污染, 是指在非特定的地

* 林业公益性行业科研专项 (201104055)、国家科技支撑专题 “村镇景观建设中的生物多样性保护技术” 项目 (2012BAJ24B0504) 和中央级公益性科研院所基金重点项目 (RISF2013001) 联合资助. $2014-03$ - 26 收稿; 201407-14 收修改稿. 孙慧(1990 ), 女, 硕士研究生; E-mail:kikotilamisu@ 163. com.

** 通信作者;E-mail:zhangk126@126.com. 
点从大气、地面或土壤中溶解的和固体的污染物在降水或融雪的冲刷下, 通过径流过程而汇人受纳水体 (包 括河流、湖泊、水库和海湾等) 并引起水体富营养化、有机污染或其他形式的污染 ${ }^{[9-10]}$. 面源污染一般来源于 农业、森林砍伐、城市与矿业等, 其中农业面源污染对水体的危害最大, 影响范围也最为广泛 ${ }^{[11-12]}$. 农业面源 污染主要来自于化肥和农药, 其中的 N、P 等营养盐因水土流失给水体带来了大量的营养物质 ${ }^{[13-16]}$. 这些营 养盐是水体产生富营养化的先决条件, 太湖的主要人湖河道因不断输人高浓度营养盐使得太湖水体富营养 化的程度不断加剧, 所以农业面源污染的治理刻不容缓 ${ }^{[15,17]}$.

吴永红等 ${ }^{[18]}$ 提出了通过 “减源一拦截一修复” (3R) 技术控制农业面源污染, 在此基础上为了更好地治理 农业面源污染, 不仅要减少污染物的排放, 而且要 “增汇”, 即通过种植防护林固定过剩的营养物质来达到生 态修复的目的. 防护林在保持水土、防止土壤侵蚀、涵养水源等方面发挥着重要的作用, 但是通过防护林控 制农业面源污染方面的研究较少 ${ }^{[19]}$. 其实防护林不仅能减缓地表径流, 而且能加速径流中沉积物的沉淀, 同 时有效地吸附、吸收溶解于水体的营养物质, 从而较好地改善地下水的水质 ${ }^{[20-21]}$.

防护林对由农耕地流入湖泊中的 N、P 等营养物质有很好的固定作用, 如 Borin 等 ${ }^{[22]}$ 调查得出 $\mathrm{N}$ 在岸边 植被带的截留率为 $89 \%$, 而在农田中的截留率仅为 $8 \%$. 同时与单一的草地缓冲带相比, 树木与草地相结合 的防护林带对 $N$ 的吸收量会增加 $20 \%{ }^{[23]}$. 不同植被及不同土地利用类型的土壤 N、P 收支决定了 N、P 在土 壤中的固定作用, 进一步影响 $\mathrm{N} 、 \mathrm{P}$ 的流失强度 ${ }^{[24]}$. 有研究表明, 竹林土壤全氮的平均含量最高, 而经济林土 壤全磷的平均含量较高 ${ }^{[25]}$. 可见, 竹林固氮能力较强, 而经济林能较好地固定土壤中的磷, 从而减少 $N 、 P$ 的 流失, 减缓湖泊富营养化的进程. 韩莹等 ${ }^{[24]}$ 提出 $\mathrm{N} 、 \mathrm{P}$ 利用率以竹林最高, 马尾松林次之, 茶园的 $\mathrm{N} 、 P$ 利用率 最低, 水田的 N、P 利用率要高于茶园. 由此得出竹林比马尾松林更有利于水环境保护, 而茶园对水环境的不 利影响超过水田. 可见, 建设沿岸防护林带对控制农业面源污染起到积极的作用, 为了探讨太湖防护林控制 农业面源污染的具体效应, 本研究将防护林土壤营养元素含量与周边农业生产施肥概况相结合, 初步分析 了该区域防护林对农业面源污染的减源一增汇效应.

\section{1 材料与方法}

\section{1 研究区概况}

太湖流域总面积 $36500 \mathrm{~km}^{2}$, 湖泊面积 $2427.8 \mathrm{~km}^{2}$. 太湖横跨苏州市、宜兴市、无锡市的滨湖区和常州市 武进区, 本研究实验地点选在了宜兴市 $\left(31^{\circ} 07^{\prime} \sim 31^{\circ} 37^{\prime} \mathrm{N}, 119^{\circ} 31^{\prime} \sim 120^{\circ} 03^{\prime} \mathrm{E}\right)$. 宜兴市位于太湖西岸, 水域面 积 $242.29 \mathrm{~km}^{2}$. 目前该市有河道 215 条, 其中有沙塘港、师渡港、荠渡港、社渡港、洪港等 14 条省控、国控河道 和 12 条市控河道共计 26 条人湖河道 ${ }^{[26]}$. 宜兴市于 2004 年开始规划生态公益林, 2007 年正式投人建设. 目 前已建设并长势良好的太湖宜兴段生态公益林主要集中在太湖大堤西侧 $250.0 \mathrm{~m}$ 和主要人湖河道上溯 $3.0 \mathrm{~km}$ 两侧 $30.0 \mathrm{~m}$ 的范围内, 以及滨湖公路两侧村庄、道路和农田防护林. 本研究以太湖湖滨带防护林造林 区为主要研究区域,开展防护林区林木和土壤调查.

\section{2 研究方法}

1.2.1 植被覆盖状况调查 根据植被类型所起的主导地位, 以约 $300 \mathrm{~m} \times 300 \mathrm{~m}$ 的方格网内各设置 1 个样 方, 乔木群落调查选用 $10 \mathrm{~m} \times 10 \mathrm{~m}$ 、灌木群落 $5 \mathrm{~m} \times 5 \mathrm{~m}$ 的样方, 草本群落调查采用 $1 \mathrm{~m} \times 1 \mathrm{~m}$ 的样方. 记录内 容包括: (1) 乔木:样方面积,每株乔木的名称、胸径、树高; (2) 灌木:样方面积,灌木名称、高度; (3) 草本: 样方面积,植物名称、株 (丛) 数、一般高度.

1.2.2 土壤样品采集 选择宜兴市生态公益林典型代表区作为实验区, 分别于 2009 年 10 月、2011 年 5 月和 2013 年 8 月进行调查、取样, 以区域代表性植被以及与太湖开阔水体的距离为原则, 选取女贞 (Ligustrum lucidum Ait) 和香樟 (Cinnamomum camphora ( L. ) Presl.) 等 8 个典型造林树种为研究对象. 在每个林分设置了 3 个面积为 $20 \mathrm{~m} \times 30 \mathrm{~m}$ 的调查、取样样地, 共设置了 24 块样地. 于每个样地内, 按 $\mathrm{S}$ 形曲线选择 5 个取样 点, 每个取样点用直径为 $5 \mathrm{~cm}$ 土钻取 $0 \sim 20 \mathrm{~cm}$ 土壤, 用布袋装好于 $4^{\circ} \mathrm{C}$ 保温箱带回实验室, 在室内自然风干 $2 \sim 3$ 周后磨碎过篮, 测定土壤 $\mathrm{C} 、 \mathrm{~N} 、 \mathrm{P}$ 和 $\mathrm{K}$ 元素的含量.

1.2 .3 元素含量测定 根据周斌等 ${ }^{[27]}$ 对土壤中元素 $\mathrm{C}$ 的测定方法, 进行 $\mathrm{C}$ 元素含量的测定. 将采集的土壤 样品烘干, 往其中加足量 $10 \%$ 的 $\mathrm{HCl}$, 去除碳酸盐; 加浓 $\mathrm{HF}$ 去除硅酸盐; 加 $0.1 \mathrm{M} \mathrm{K}_{2} \mathrm{Cr}_{2} \mathrm{O}_{7} / 2 \mathrm{M} \mathrm{H}_{2} \mathrm{SO}_{4}$ 溶液去 
除有机碳, 最后的残留物即为元素 $\mathrm{C}$. 把残留物装人样品管, 于 $800^{\circ} \mathrm{C}$ 高温下通过催化剂 $\left(\mathrm{Cu}^{2+}\right)$ 催化, 在氧化 炉中灼烧, 定量转化为 $\mathrm{CO}_{2}$, 冷阱收集纯化后的 $\mathrm{CO}_{2}$ 通过微压力计测定气体压力, 进而计算出元素 $\mathrm{C}$ 的含量. 总氮的测定采用半微量凯氏法, 在采集的土壤样品中加人硫酸铜、硫酸钾与硒粉, 用浓硫酸消煮, 使其转变 为硫酸铵, 然后用氢氧化钠碱化, 加热蒸馏出氨, 经嗍酸吸收, 用标准酸滴定其含量 ( LY/T 1288-1999). 总 磷的测定采用碱熔一钼锑抗比色法, 将采集的土壤样品在银坩埚中用氢氧化钠高温熔融, 然后用水溶解熔融 物后加人钼锑抗显色剂, 使用分光光度计进行测定 ( LY/T 1232-1999). 总钾的测定采用碱熔一火焰光度法, 将样品在银坩埚中用氢氧化钠高温熔融, 用水溶解熔融物, 待测液用火焰光度计测定 ( LY/T 1234-1999).

\section{2 结果与分析}

\section{1 宜兴防护林和草本调查}

2.1 .1 防护林建设状况 2009 年初至 2010 年末, 宜兴新增林地 $56.67 \mathrm{~km}^{2}$, 其中太湖景观防护林 $40 \mathrm{~km}^{2}$, 经 济林 (包括能源林) $13.33 \mathrm{~km}^{2}$, 用材林 $3.33 \mathrm{~km}^{2}$, 森林覆盖率增加 $2.78 \%$, 达到 $31.38 \%$, 村庄绿化覆盖率为 38\% (图 1). 湖滨防护林建设包括:

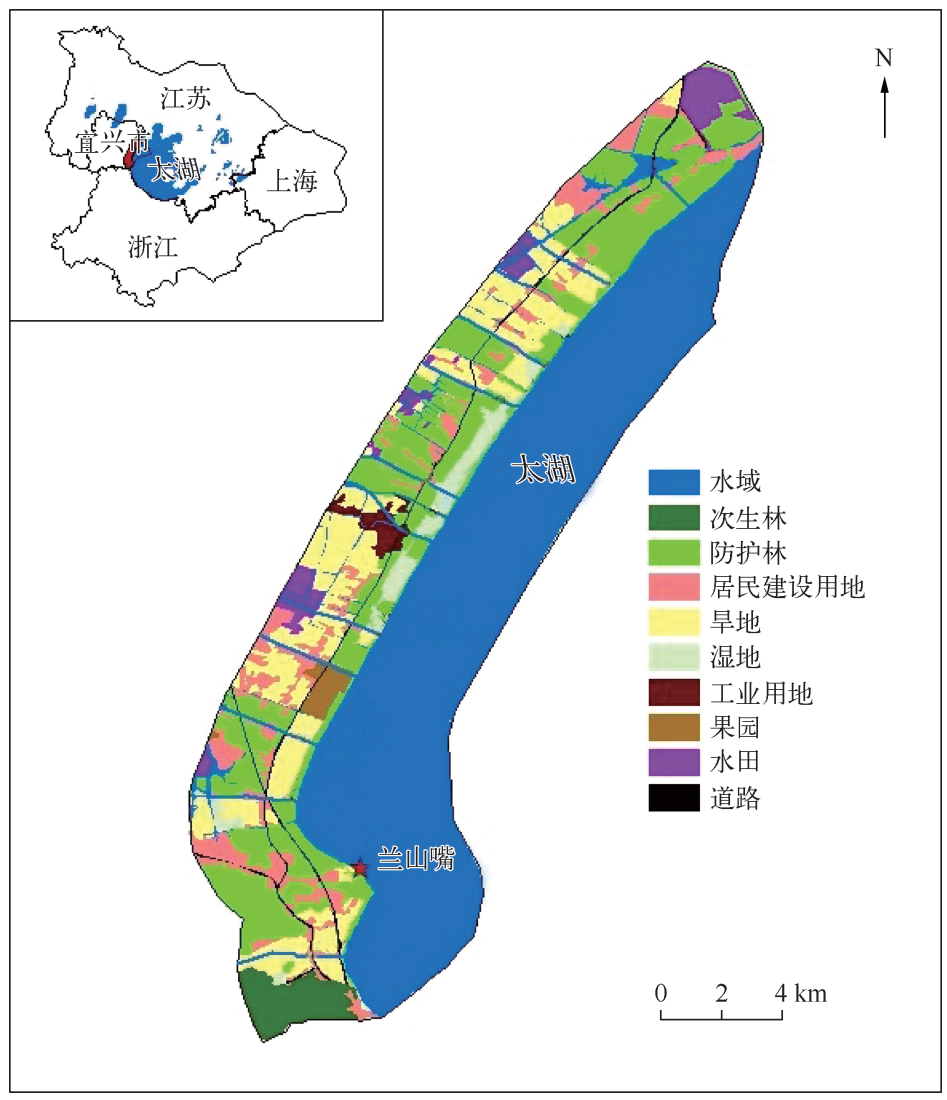

图 12010 年太湖流域宜兴段防护林分布

Fig. 1 Protection forest distribution of Yixing section of Lake Taihu watershed in 2010

1) 沿太湖 $200 \mathrm{~m}: 2008$ 年完成沿太湖 $40 \mathrm{~km} \times 200 \mathrm{~m}$ 的太湖景观防护林建设, 面积为 $8 \mathrm{~km}^{2}$, 品种以乡土 水源涵养落叶树种和常绿树种为主. 其中, 乡土水源涵养落叶树种有: 银杏 (Ginkgo biloba)、喜树 (Camptotheca acuminata)、枫杨 (Pterocarya stenoptera C. DC)、朴树 (Celtis sinensis)、榆树 (Ulmus pumila)、臭椿 (Ailanthus altissima)、黄连木 ( Pistacia chinensis)、苦楝 (Melia azedarach Linn.)、榇树 (Koelreuteria paniculata)、槐树 (Sophora japonica L. )、青桐 (Firmiana simplex)、乌柏(Chinese tallow)、水杉(Metasequoia glyptostroboides)、池 
杉( Taxodium ascendens Brongn)、落羽杉(Taxodium distichum( L. ) Rich. )、楸树 (Catalpa bungei) 、七叶树 (Aesculus chinensis)、合欢 (Albizia julibrissin Durazz.) 等; 常绿树种有冬青 (Ilex chinensis Sims)、杜英 (Elaeocarpus decipiens Hemsl.) 、女贞、红豆杉( Taxus chinensis)、桂花(Osmanthus fragrans)、法国冬青(Viburnum awabuki K. Koch)、含笑(乔木) (Michelia figo) 和木荷 (Schima superba Gardn. et Champ.) 等. 混交比例: 常绿树种/落叶树 种为 $3 / 7$; 针叶林/阔叶林为 $3 / 7$; 上层落叶大乔木占 $70 \%$; 营林树种达 100 个以上. 采取胸径 $5 \mathrm{~cm}$ 以上的苗 木造林,株行距为 $3 \mathrm{~m} \times 4 \mathrm{~m}$, 其中杉科楖种株行距为 $2 \mathrm{~m} \times 2 \mathrm{~m}$, 采取带状混交和块状混交.

2) 沿太湖 $1 \mathrm{~km}: 2009$ 年完成建设 $1 \mathrm{~km}$ 地区太湖景观防护林建设, 造林面积 $20 \mathrm{~km}^{2}$, 利用上述品种进行 带状或块状混交造林.

3) 沿太湖 $5 \mathrm{~km}: 2010$ 年完成 $5 \mathrm{~km}$ 地区上述品种太湖景观防护林建设, 重点是大四旁造林, 造林面积 $12 \mathrm{~km}^{2}$, 其中发展枇杷等经济林果 $3.33 \mathrm{~km}^{2}$.

4) 沿太湖 $5 \mathrm{~km}$ 以外地区: 2008-2009 两年内完成 $5 \mathrm{~km}$ 以外地区上述品种的造林建设, 重点是上溯 $10 \mathrm{~km}$ 和 $50 \mathrm{~km}$ 人湖河道防护林建设,面积 $16.67 \mathrm{~km}^{2}$.

2.1 .2 防护林带草本调查 研究区共有野生草本植物 21 科 64 种, 其中优势科为禾本科 17 种、菊科 17 种, 较优势科为蓼科 6 种、藜科和唇形科各 3 种、豆科和苋科各 2 种. 与农田草本植物对比,防护林带内物种丰 富, 群落结构正逐步恢复和优化, 在遮荫区域, 群落结构以耐荫草本植物 (小蓬草 (Conyza canadensis ( L.) Cronq. )、一年蓬 (Erigeron annuus ( L. ) Pers. (Aster an-nuus L. ))、三叶草 (Trifolium) 和艾草 (Blumea aromatria ) ) 为绝对优势种, 呈斑块状分布在防护林带内遮荫区域, 其它物种为伴生种; 在林窗、林缘和林带外侧等 光照充足区域, 为多物种混交群落结构.

\section{2 防护林减源增汇作用}

防护林带通过减少土壤养分的输人 (减源)、增加土壤养分的输出 (增汇), 实现对土壤养分的降低作 用. 减源途径主要是在生态防护区域彻底杜绝人工施肥, 增汇途径主要是林木生长的吸收、自身养分的逐年 累积.

2.2.1 防护林的减源作用通过实地调查, 调研了定溪村、双桥村、西望村等 31 个自然村, 对自然村的耕地 类型、种植作物、种植面积、轮作方式、氮肥和磷肥施用量等农业生产基本情况作详细记录,汇总于表 1 .

防护林建成后, 可有效减少研究区氮肥和磷肥的输人, 每年可减少输人总氮 $41.23 \sim 64.47 \mathrm{~g} / \mathrm{m}^{2}$, 减少 输人 $\mathrm{P}_{2} \mathrm{O}_{5} 7.08 \sim 15.14 \mathrm{~g} / \mathrm{m}^{2}$. 以示范区 $16 \mathrm{~km}^{2}$ 防护林面积计, 共计每年可减少输人总氮 $6.6 \times 10^{5} \sim 1.03 \times$ $10^{6} \mathrm{~kg}$, 可减少输人 $\mathrm{P}_{2} \mathrm{O}_{5} 1.13 \times 10^{5} \sim 2.42 \times 10^{5} \mathrm{~kg}$ (表 1 ).

表 1 研究区自然村(31 个)农业生产基本情况 *

Tab. 1 The basic situation of agricultural production in 31 natural villages of study area

\begin{tabular}{cccccc}
\hline 耕地类型 & 种植作物 & 种植面积 $/ \mathrm{km}^{2}$ & 轮作方式 & $\begin{array}{c}\text { 氮肥施用量/ } \\
\left(\mathrm{g}(\text { 纯氮 }) /\left(\mathrm{m}^{2} \cdot \mathrm{a}\right)\right)\end{array}$ & $\begin{array}{c}\text { 磷肥施用量/ } \\
\left(\mathrm{g}\left(\mathrm{P}_{2} \mathrm{O}_{5}\right) /\left(\mathrm{m}^{2} \cdot \mathrm{a}\right)\right)\end{array}$ \\
\hline 旱地 & 蔬菜 & 14.34 & 一年三季 & 64.47 & 15.14 \\
水田 & 水稻、麦(油菜) & 31.65 & 水旱轮作 & 41.23 & 7.08 \\
林地 & 经济林、公益林 & 40.73 & $\mathrm{NH}$ & $\mathrm{NH}$ & $\mathrm{NH}$ \\
\hline
\end{tabular}

* NH 表示无轮作和无施肥.

2.2.2 防护林的增汇作用 对研究区主要造林树种的营养元素含量进行了分析,得到表 2 .

在全球尺度上, 郁闭森林的地上生物量与树高之比为一常数, 即 $1.06 \mathrm{~kg} / \mathrm{m}^{3}$, 也就是说, 单位森林空间 的地上生物量密度恒定, 为 $1.06 \mathrm{~kg} / \mathrm{m}^{3}$ (均以干物质量计) ${ }^{[28]}$. 主要造林树种如柳树、香樟、女贞、奕树、杨 树、重阳木、雪松和水杉的平均树高为 $4.26 \pm 1.03 \mathrm{~m}$ (2009 年)、 $5.44 \pm 1.25 \mathrm{~m}$ (2011 年) 和 $8.25 \pm 0.85 \mathrm{~m}$ (2013 年), 以此计算湖滨岸防护林地上生物量大概为 $4.52 \mathrm{~kg} / \mathrm{m}^{2}$ (2009 年)、5.77 kg/m $\mathrm{m}^{2}$ (2011 年) 和 $8.75 \mathrm{~kg} / \mathrm{m}^{2}$ (2013 年); 根据表 2 所示, 上述主要造林树种 $\mathrm{C} 、 \mathrm{~N} 、 \mathrm{P}$ 和 $\mathrm{K}$ 的平均含量分别为 $539.71 \pm 35.11$ 、 $4.06 \pm 0.90 、 0.55 \pm 0.17$ 和 $2.97 \pm 0.57 \mathrm{~g} / \mathrm{kg}$; 利用地上生物量乘以 $\mathrm{C} 、 \mathrm{~N} 、 \mathrm{P}$ 和 $\mathrm{K}$ 的平均含量即可估算出防护 林每平方米地上部分固定的 C、N、P 和 K 的量. 由此得出 2009 年 10 月份时, 防护林地上部分固定的 $C 、 N 、 P$ 
和 $K$ 分别为 $2439.48 、 18.34 、 2.48$ 和 $13.42 \mathrm{~g} / \mathrm{m}^{2}$ (单位面积总量);2011 年 5 月份时, 固定量分别为 3114.12 、 $23.42 、 3.16$ 和 $17.13 \mathrm{~g} / \mathrm{m}^{2}$; 而 2013 年 8 月份时, 固定量分别为 $4722.46 、 35.53 、 4.81$ 和 $25.99 \mathrm{~g} / \mathrm{m}^{2}$, 相比 2009 年,分别增加了 $93.6 \% 、 93.7 \% 、 94.0 \%$ 和 93.7\%. 2009 年 10 月份至 2011 年 5 月份,防护林新增养分 固定量 $\triangle C 、 \triangle N 、 \triangle P$ 和 $\triangle K$ 分别为 674.64、5.07、0.69 和 $3.71 \mathrm{~g} / \mathrm{m}^{2}$; 而 2011 年 5 月份至 2013 年 8 月份,防 护林新增养分固定量 $\triangle C 、 \triangle N 、 \triangle P$ 和 $\triangle K$ 分别为 $1608.34 、 12.11 、 1.65$ 和 $8.86 \mathrm{~g} / \mathrm{m}^{2}$. 每隔两年防护林地上 部分固定的 $\mathrm{C} 、 \mathrm{~N} 、 \mathrm{P}$ 和 $\mathrm{K}$ 的量增长趋势见图 2 .

表 2 主要造林树种营养元素含量

Tab. 2 The main nutrition elements content of several kinds of afforestation tree

\begin{tabular}{lcccc}
\hline 树种 & $\mathrm{C} /(\mathrm{g} / \mathrm{kg})$ & $\mathrm{N} /(\mathrm{g} / \mathrm{kg})$ & $\mathrm{P} /(\mathrm{g} / \mathrm{kg})$ & $\mathrm{K} /(\mathrm{g} / \mathrm{kg})$ \\
\hline 女贞 & $515.33 \pm 39.36$ & $4.11 \pm 0.05$ & $0.60 \pm 0.20$ & $3.17 \pm 0.20$ \\
香樟 & $537.33 \pm 33.07$ & $3.44 \pm 0.88$ & $0.40 \pm 0.24$ & $2.05 \pm 1.41$ \\
柳树 (Salix babylonica) & $565.33 \pm 61.82$ & $4.11 \pm 0.05$ & $0.60 \pm 0.20$ & $3.17 \pm 0.20$ \\
杨树 (Populus) & $517.00 \pm 12.03$ & $3.44 \pm 0.88$ & $0.40 \pm 0.24$ & $2.05 \pm 1.41$ \\
栾树 & $485.33 \pm 56.05$ & $5.83 \pm 0.11$ & $0.54 \pm 0.02$ & $3.25 \pm 0.02$ \\
重阳木 (Bischofia polycarpa(levl. )) & $565.67 \pm 22.87$ & $3.22 \pm 0.12$ & $0.32 \pm 0.01$ & $3.48 \pm 0.28$ \\
雪松 (Cedrus deodara(Roxb. ) G. Don) & $535.33 \pm 44.19$ & $4.88 \pm 1.38$ & $0.87 \pm 0.17$ & $3.28 \pm 1.94$ \\
水杉 & $596.33 \pm 4.19$ & $3.45 \pm 0.40$ & $0.63 \pm 0.06$ & $3.30 \pm 0.18$ \\
\hline
\end{tabular}

\section{3 防护林对农业面源污染的效应分析}

1) 太湖景观防护林建设面积逐年增加,基本于 2010 年建成. 防护林建设除发展乡土水源涵养树 种外, 还营建了经济林果和用材林. 同时在防护林林窗、林缘和林带内外侧等区域,都生长着丰富的草 本植物. 防护林的建设增加了太湖流域的物种丰富度,改善太湖生态环境的同时也给太湖带来了经济 效益.

2) 防护林的建成,有效地减少了研究区氮肥和磷肥的输人,防护林地上部分固定的 C、N、P 和 K 的量也 呈现逐年增长的趋势 (图 2). 至 2011 年底, 生态恢复区土壤的总氮和总磷负荷分别减少了 $46.30 \sim 69.54 \mathrm{~g} / \mathrm{m}^{2}$ 和 $3.78 \sim 7.30 \mathrm{~g} / \mathrm{m}^{2}$. 与农田土壤相比, 防护林土壤的有机质和有效钾含量降低率分别为 $29.06 \%$ 和 $26.33 \%$, 总氮、总磷和有效磷的降低率分别为 $34.47 \% 、 41.92 \%$ 和 $52.82 \%$. 可见,防护林降低引 起水体富营养化的营养盐含量效果显著, 比种植农作物带来的生态价值高.
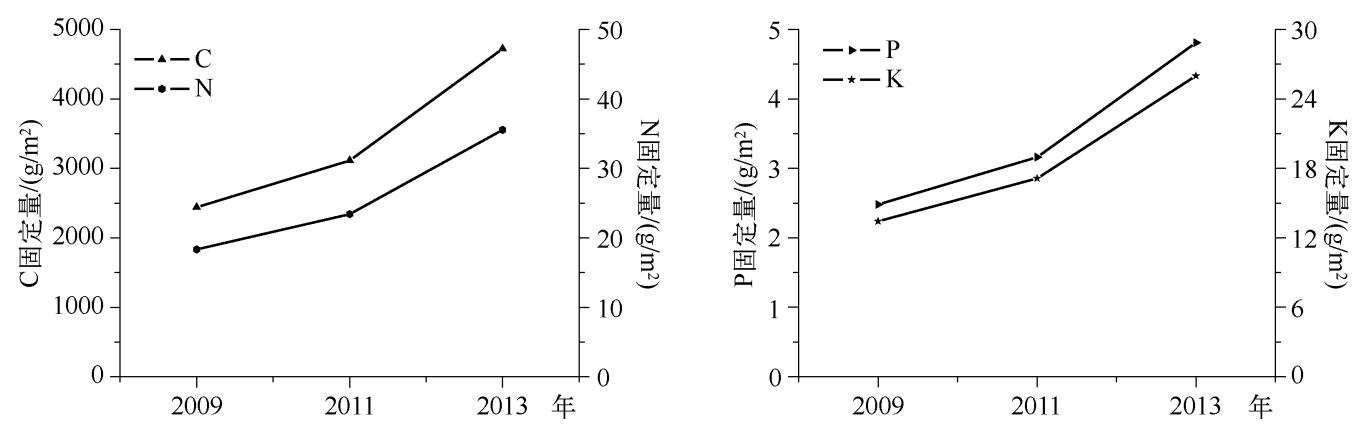

图 2 2009-2013 年防护林固定的 C、N、P 和 K 含量

Fig. 2 C, N, P and K fixed by the shelter forest during 2009-2013

3) 防护林对控制农业面源污染有积极的作用, 通过太湖防护林的建设可以有效地控制面源污染, 净化 太湖水质, 同时营造健康的湖滨带植被缓冲带, 严格控制滨岸带的开发强度和管控方式 ${ }^{[29-30]}$, 同时也使我们 认识到防护林建设具有巨大的生态价值和生产效益,应充分发挥其作用并加以推广. 


\section{3 讨论}

根据张彪等 ${ }^{[31]}$ 提供的土壤侵蚀模数法和土壤养分含量估算了防护林控制土壤侵蚀及其减少 N、P 的养 分流失量. 太湖流域不同土地利用类型的土壤侵蚀速率是不同的, 无林地 (即耕作土土壤侵蚀速率) 为 $1681.2 \mathrm{t} /\left(\mathrm{km}^{2} \cdot \mathrm{a}\right)^{[32]}$, 混交林为 $186.6 \mathrm{t} /\left(\mathrm{km}^{2} \cdot \mathrm{a}\right)^{[33]}$ (太湖流域防护林以混交林为主). 以无林地土壤侵 蚀速率为对照, 防护林控制土壤侵蚀量计算公式为:

$$
S=\left(S_{\text {non }}-S_{\mathrm{f}}\right) A
$$

式中, $S$ 为森林年控制土壤侵蚀量 $(\mathrm{t} / \mathrm{a}), S_{\text {non }}$ 为非林地年土壤侵蚀速率 $\left(\mathrm{t} /\left(\mathrm{km}^{2} \cdot \mathrm{a}\right)\right), S_{\mathrm{f}}$ 为不同林地类型年 土壤侵蚀速率 $\left(\mathrm{t} /\left(\mathrm{km}^{2} \cdot \mathrm{a}\right)\right), A$ 为林地面积 $\left(\mathrm{km}^{2}\right)$.

由宜兴新增林地 $56.67 \mathrm{~km}^{2}$ 得出, 防护林可控制 $8.47 \times 10^{4} \mathrm{t}$ 土壤免于水土流失, 即固持了 $8.47 \times 10^{4} \mathrm{t}$ 土壤. 防护林在控制土壤侵蚀发生的同时, 也减少了土壤养分 N、P 的流失. 防护林通过控制土壤侵蚀减少的 养分流失量计算公式为:

$$
N=S \cdot \beta_{i}
$$

式中, $N$ 为控制土壤侵蚀减少的总氮或总磷养分流失量 $(\mathrm{t} / \mathrm{a}), \beta_{i}$ 为林地土壤总氮或总磷养分含量 $(\mathrm{g} / \mathrm{kg})$.

防护林主要造林树种 N、P 的平均含量分别为 4.06 和 $0.55 \mathrm{~g} / \mathrm{kg}$, 故防护林因其土壤保持功能, 可避免 $343.88 \mathrm{t}$ 总氮和 $46.59 \mathrm{t}$ 总磷发生流失. 虽然本讨论所引用的参数来源于文献查找和实验数据, 不能精准地 反映太湖流域宜兴段防护林土壤侵蚀及养分流失量, 但是可使人们充分认识到建设太湖流域防护林的重要 性, 为以后太湖流域面源污染的治理和保护指出新方向. 从防护林控制土壤总氮、总磷流失量的效果来看, 在宜兴市建设防护林体系逐步完善的过程中, 防护林的减源一增汇效果会逐步提高, 将更好地控制农业面源 污染的排放以及改善太湖水体的水质.

\section{4 参考文献}

[ 1 ] 间丽珍,石敏俊,王 否. 太湖流域农业面源污染及控制研究进展. 中国人口・资源与环境,2010,20(1):99-107.

[2] 高柳青,晏维金. 富营养化对三湖水环境影响及防治探讨. 资源科学,2002,24(3):19-25.

[3] 吕振霖. 太湖水环境综合治理的实践与思考. 河海大学学报: 自然科学版,2012,40(2):123-128.

[ 4 ] 丁莞歆. 中国水污染事件纪实. 环境保护,2007,(14):83-85.

[ 5 ] 柴世伟,裴晓梅,张亚雷等.农业面源污染及其控制技术研究. 水土保持学报,2006,20(6):192-195.

[ 6 ] 沃飞,陈效民, 吴华山等. 太湖流域典型地区农村水环境氮、磷污染状况的研究. 农业环境科学学报, 2007,26 (3) :819-825.

[ 7 ] 张维理, 武淑霞, 冀宏杰等. 中国农业面源污染形势估计及控制对策 I - 21 世纪初期中国农业面源污染的形势估 计. 中国农业科学, 2004,37(7):1008-1017.

[ 8 ] 全为民,严力蛟. 农业面源污染对水体富营养化的影响及其防治措施. 生态学报,2002,22(3):291-299.

[ 9 ] 陈吉宁,李广贺,王洪涛. 滇池流域面源污染控制技术研究. 中国水利,2004,(9):47-50.

[10］汪 洪,李录久,王凤忠等. 人工湿地技术在农业面源水体污染控制中的应用. 农业环境科学学报,2007,26(B10)： 441-446.

［11］崔 键,马友华,赵艳萍等.农业面源污染的特性及防治对策. 中国农学通报,2006,22(1):335-340.

[12] 陶 春,高 明,徐畅等. 农业面源污染影响因子及控制技术的研究现状与展望. 土壤,2010,42(3):336-343.

[13］杨林章,王德建,夏立忠. 太湖地区农业面源污染特征及控制途径. 中国水利,2004,(20):29-30.

[14] 朱兆良,孙 波,杨林章等.我国农业面源污染的控制政策和措施. 科技导报,2005,23(4): 47-51.

[15] 王艳丽,张冬梅, 李春阳. 农田氮磷流失对水体富营养化的影响及防治对策. 现代农业科技,2012,(3):305.

[16] 可 欣,于维坤,尹 炜等. 小流域面源污染特征及其控制对策. 环境科学与技术,2009,32(7):201-205.

[17］程 波,张 泽,陈 凌等.太湖水体富营养化与流域农业面源污染的控制. 农业环境科学学报,2005,24(增刊)： 118-124.

[18］吴永红,胡正义,杨林章.农业面源污染控制工程的“减源一拦截一修复” (3R) 理论与实践. 农业工程学报,2011,27 
(5) $: 1-6$.

[19] 冯丽娟,封 莉,孙德智等. 防护林植被体系对面源污染物氮磷的去除作用. 哈尔滨商业大学学报: 自然科学版, $2010,(5): 548-550$.

[20] 吴殿鸣,薛建辉,吴永波. 生态防护林减轻农田氮素面源污染的研究进展. 南京林业大学学报: 自然科学版,2011, 35 (6) : 134-138.

[21] 刘世海,余新晓,于志民. 密云水库集水区人工油松水源保护林降水化学性质研究. 应用生态学报,2001,12(5): 697-700.

[22] Borin M, Bonaiti G, Santamaria G et al. A constructed surface flow wetland for treating agricultural waste waters. Water Science and Technology, 2001, 44(11/12):523-530.

[23] Lee KH, Isenhart TM, Schultz RC. Sediment and nutrient removal in an established multi-species riparian buffer. Journal of Soil and Water Conservation, 2003, 58(1):1-8.

[24] 韩 莹, 李恒鹏, 聂小飞等. 太湖上游低山丘陵地区不同用地类型氮、磷收支平和特征. 湖泊科学, 2012,24(6): 829-837.

[25] 张灿强,张 彪, 杨艳刚等. 太湖上游西苕溪近岸森林土壤氮磷养分差异特征. 水土保持学报,2011,25(5):53-58.

[26] 王 瑛,张建锋,陈光才等. 基于 “源一汇” 景观的太湖宜兴段人湖港口水质时空变化. 生态学杂志,2012,31 (2) : $399-405$.

[27] 周 斌, 沈承德, 易惟熙等. 土壤中元素碳的测定与研究. 土壤与环境, 2002,11(2):133-135.

[28 ] Fang J, Brown S, Tang Y et al. Overestimated biomass carbon pools of the northern mid-and high latitude forests. Climatic Change, 2006, 74(1/2/3):355-368.

[29] 吴建强, 黄沈发, 吴 健等. 缓冲带径流污染物净化效果研究及其与草皮生物量的相关性. 湖泊科学, 2008,20(6): $761-765$.

[30] 李恒鹏, 陈伟民, 杨桂山等. 基于湖库水质目标的流域氮, 磷减排与分区管理一以天目湖沙河水库为例. 湖泊科 学, 2013,25(6): 785-798.

[31] 张彪, 董敦义, 张灿强等. 太湖流域安吉县森林控制土壤侵蚀及养分流失的效益评估. 水土保持研究, 2011, 18 (6) : $: 111-118$.

[32] 王金否, 兴励杰, 金平华等. ${ }^{137} \mathrm{Cs}$ 法应用于流域土壤侵蚀初步研究一以太湖上游浙江省安吉县西苦溪为例. 南 京大学学报:自然科学,2003,39(6): 788-796.

[33] 曾海鳌, 吴敬禄, 林 琳. ${ }^{137} \mathrm{Cs}$ 示踪法研究太湖流域土壤侵蚀分布与总量. 海洋地质与第四纪地质, 2008, 28 (2): 79-85. 